-Technological Report-

\title{
Portable Fuel Cell System for Telecommunications Use
}

\author{
Maki ISHIZAWA*, Yutaka KUWATA, Masaaki TAKEUCHI, Katsuhisa KIMATA \\ and Tsutomu OGATA
}

Received December 20, 1995 ; Accepted February 27, 1996

NTT has developed a portable fuel cell system (PFCS) for telecommunications systems. The PFCS consists of a small fuel cell, a hydrogen cylinder, a $55 \mathrm{~V} \mathrm{DC-DC} \mathrm{converter} \mathrm{and} \mathrm{a} \mathrm{carrier.}$ The PFCS supplies $250 \mathrm{~W}$ of DC power for 5 hours using the $10.5 \ell$ hydrogen cylinder. The system can be moved easily by using the carrier. The DC-DC converter can allocate the current equally to each PFCS, and the parallel connections between the PFCSs increase the power that can be generated for telecommunications equipment. Simultaneous operation of three PFCSs provides enough power to operate a telecommunications system in a building. The operation remains stable whether commercial power is discontinued intentionally or unintentionally. The PFCS generates power quietly and cleanly, and proved to be used as an indoor emergency power source for telecommunications systems.

\section{INTRODUCTION}

NTT has been developing a power source system using phosphoric acid fuel cells for telecommunications use in view of the energy costs and the environment preservation. We are now conducting field tests of fuel cell energy systems at the NTT Kansai Network Center (200 kW system) and at the NTT Yokohama Branch $(100 \mathrm{~kW}$ system $)^{1 \sim 5}$. On the other hand, small scale fuel cells that generate energy cleanly and quietly, are expected as portable emergency power sources for telecommunications equipments in buildings ${ }^{6-8)}$.

The supply of an electrical power to telecommunications equipments in the buildings should be ensured for a continuous telecommunications service, even if the supply of commercial power to buildings is interrupted by inspection of the power equipment or by some accidents. In such cases, a portable engine is transported to the building. However, such portable engines cannot operate indoors near

NTT Interdisciplinary Research Laboratories, Nippon Telegraph and Telephone Corporation (9-11, Midori-Cho 3-Chome Musashino-Shi, Tokyo, 180, Japan)

Key Words: Phosphoric Acid Fuel Cell, Portable, Cylinder, Emergency Power telecommunications equipment, because they are noisy and toxic gas exhaust is emitted. Thus the portable engine must be wired to the telecommunications equipment for a long distance from outside of the building.

In contrast to this, a fuel cell that generates energy cleanly and quietly could be used as an indoor emergency power system. In particular, a small scale fuel cell that uses hydrogen fuel could be used in this way. Hydrogen fuel is condensed into a hydrogen cylinder, thereby improving portability. By using several PFCSs simultaneously with load sharing characteristics in DC-DC converter, enough power could be generated for a telecommunications equipment. This paper describes such a portable fuel cell system. It also reports the operation characteristics and their reliability when the system is connected to telecommunications equipment as a back-up power source.

\section{SYSTEM CONSTITUTION}

Figures 1 and 2, and table 1 show the system configuration, the appearance, and the specifications of the PFCS for supplying energy to a telecommunications equipment. Usually energy is supplied by a stable $48 \mathrm{~V}$ direct-current power source from a rectifier, operated by commercial power. The telecommunications system 
has batteries for short-term interruptions of commercial power. Several PFCSs can supply enough power to the telecommunications system in case of a long-term interruption of the commercial power.

The PFCS that generates the rated power of $250 \mathrm{~W}$ consists of a small fuel cell unit and a fuel supply unit. The small fuel cell unit is composed of a cell stack, a DC-DC converter, a controller for the output power, a fuel flow rate regulator and a remote operation equipment, and subsidiary equipments. The system weighs about $30 \mathrm{~kg}$, and can be carried by one person. The cell stack is composed of 30 cells of which the electrode area is $190 \mathrm{~cm}$ and the temperature of the cell stack is regulated at $120^{\circ} \mathrm{C}$. The fuel hydrogen is supplied to the cell stack with the pressure which is slightly higher than the atmospheric pressure. The DC-DC converter, which converts cell stack voltage to 54.6 $\mathrm{V}$ of direct current voltage based on the needs of telecommunications equipment, provides stable output voltage to a telecommunications equipment, also charges the lead-acid batteries simultaneously, and controls the output current if the current exceeds $4.6 \mathrm{~A}$. Furthermore, the DC-DC converter can allocate the current equally to each PFCS, and the parallel connections between the PFCSs increases the power that can be generated for a telecommunications equipment ${ }^{7}$.

The fuel supply unit consists of the hydrogen cylinder, a fuel supply, a safety device consisting of a valve-shutter and hydrogen sensor, and a carrier. The fuel tank is $10.5 \ell, 11 \mathrm{~kg}$ hydrogen cylinder, making it easy to install, portable and inexpensive. The hydrogen cylinder can be attached to the carrier and moved easily. The hydrogen cylinder is filled at a pressure of $150 \mathrm{~kg} / \mathrm{cm}^{\prime}$, and can generate power of $250 \mathrm{~W}$ for about 5 hours. The fuel supply unit and the fuel cell unit are assembled on the carrier. To prevent hydrogen from leaking, a valve-shutter shuts the main valve of the hydrogen cylinder if the

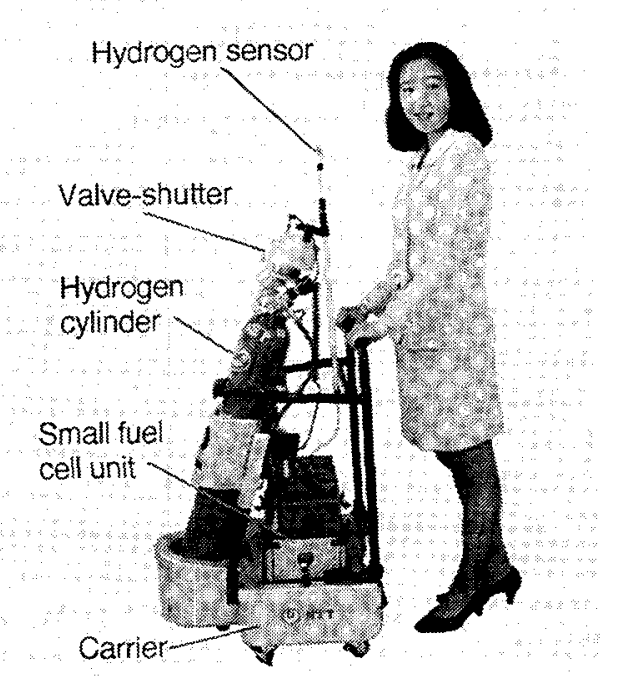

Fig. 2 Picture of the PFCS.

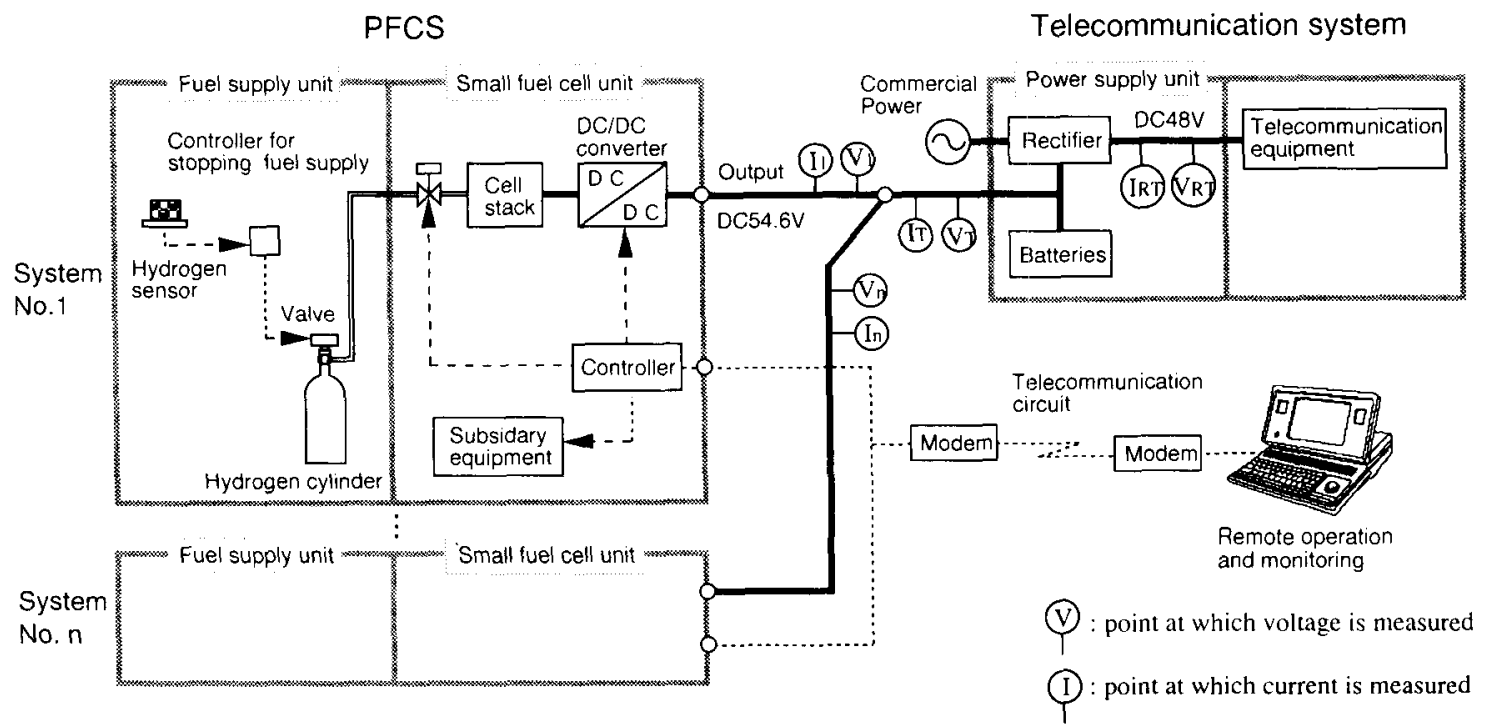

Fig. 1 System Configuration of the PFCS. 
hydrogen sensor on top of the carrier senses hydrogen leakage.

When there is a periodic inspection of power equipment in a building, or an announcement of power interruption from the power company, an operator connects the PFCS beforehand to the telecommunications system in the building. The PFCS can be operated and monitored through a telecommunications circuit from the operation center.

\section{ADAPTABILITY OF PFCS TO TELECOMMUNICATIONS SYSTEMS}

\subsection{Supplying power to the telecommunications system}

There are two cases where the PFCS supplies emergency power. In the first case, when a commercial power interruption is announced in advance, the PFCS can be prepared beforehand in the building. In this case, the PFCS is connected to the telecommunications system and supplies power under the same condition as what the telecommunications system is operated by the commercial power. Then, when commercial power is interrupted, the PFCS supplies power independently. When commercial power is resumed, the PFCS stops supplying power and is disconnected. The PFCS must supply stable power and operate quietly.

In the second case, commercial power is interrupted abruptly without warning, and the PFCS must be transported as quickly as possible. In this case, the PFCS is then connected to the telecommunications system and supplies power where the telecommunications system is being operated by the battery or already stopped. Here also the PFCS must supply stable power and operate quietly.

The telecommunications system selected Remote Terminals (RT), which were installed by using optical fiber cables with the subscriber network in one corner of each floor of a building in a business area $a^{9-12)}$. One type of RT used in this study and the specifications of the power supply unit of the RT are shown in Table 2. The RT power unit for 400 subscribers supplies $48 \pm$ $5 \mathrm{~V}, 9 \mathrm{~A}$ power to the telecommunications equipment and charges the batteries. The power of RT unit is normally supplied by $100 \mathrm{~V} \mathrm{AC}$
Table 1 Specifications of the PFCS.

\begin{tabular}{|c|c|}
\hline Rated Power & $250 \mathrm{~W}^{* 1}$ \\
\hline Output Voltage & Nominally DC54.6 V \\
\hline Output Current & Up to $4.6 \mathrm{~A}$ \\
\hline Dimensions & $\mathrm{L} 500 / \mathrm{W} 400 / \mathrm{H} 900 \mathrm{~mm}$ \\
\hline Weight & $30 \mathrm{~kg} * 2$ \\
\hline Start-up Time & $5 \mathrm{~min}$ \\
\hline Fuel Type & Hydrogen \\
\hline Fuel Tank & $\begin{array}{l}\text { High Pressure Cylinder } \\
\text { Weight } 11 \mathrm{~kg} \text {, }\end{array}$ \\
\hline & Volume $10.5 \ell$ \\
\hline Operation time & $5 h^{* 3}$ \\
\hline Noise level & $40 \mathrm{~dB}$ \\
\hline $\begin{array}{l}\text { Remote operation } \\
\text { function }\end{array}$ & $\begin{array}{l}\text { Remote start-up, } \\
\text { monitoring and stop }\end{array}$ \\
\hline Safety function & $\begin{array}{l}\text { Senses hydrogen leaks, } \\
\text { and has automatic } \\
\text { valve-shutting function }\end{array}$ \\
\hline \multicolumn{2}{|c|}{$\begin{array}{l}\text { * } 1 \text { Power can be increased by using several PFCS } \\
\text { simultaneously. }\end{array}$} \\
\hline \multicolumn{2}{|c|}{ * 2 Weight of PFCS without the hydrogen cylinder. } \\
\hline *3 Generating time & $\begin{array}{l}\text { tt rated power when using } \\
\text { ylinder. }\end{array}$ \\
\hline
\end{tabular}

Table 2 Specifications of the RT power unit.

\begin{tabular}{|c|c|c|}
\hline \multirow{3}{*}{ Output Power } & voltage & $\mathrm{DC} 48 \pm 5 \mathrm{~V}$ \\
\hline & current & $9 \mathrm{~A}$ \\
\hline & $\begin{array}{l}\text { noise } \\
\text { voltage }\end{array}$ & $<5 \mathrm{mV}$ \\
\hline $\begin{array}{l}\text { Commercial } \\
\text { Power }\end{array}$ & & $\mathrm{AC} 100 \mathrm{~V}$ \\
\hline \multirow{4}{*}{ Battery Power } & voltage & $\mathrm{DC} 48 \mathrm{~V}$ \\
\hline & capacity & $38 \mathrm{Ah}$ \\
\hline & weight & $64 \mathrm{~kg}$ \\
\hline & volume & $0.027 \mathrm{~m}^{3}$ \\
\hline \multirow{2}{*}{ PFCS power } & voltage & DC54.6 V \\
\hline & number & 3 \\
\hline
\end{tabular}

commercial source, and is supplied from batteries during short term interruption of $\mathrm{AC}$ power. The PFCS supplies power in the case of long term interruption of $A C$ power. The supply voltage from the PFCS to the power unit is set at $54.6 \mathrm{~V}$, which is slightly higher than the output voltage for the telecommunications equipment. There are three PFCSs to generate enough power for the RT. The 
noise voltage must be less than $5 \mathrm{mV}$ when the $\mathrm{RT}$ is operated by the PFCSs.

As mentioned above, the RT and the PFCSs must be able to operate stably during the transition period, where switching from commercial source to PFCS power, or vice versa take place, or during the long-term PFCS power generation.

\subsection{Long-term reliability of the PFCS}

The PFCS is generally used for short time periods, and also used many times. This is quite different from on site fuel cell, which must generate power continuously for a long time period. The cycle operation performances of the cell were studied by Nakatoh et $\mathrm{a}^{6)}$. The cell was confirmed to be able to run stably up to 600 cycles. On the other hand, depending on the circumstances, the PFCS may be required to generate power abruptly in emergency cases after it has not been used for a long time. In accordance with such situations, the PFCS's long range reliability was evaluated. Its storage properties, and the decrease in cell voltage after storage were also evaluated.

\section{OPERATION TESTS}

\subsection{Power supply characteristics}

The performance of PFCS for the first case is monitored where a commercial power interruption is announced in advance and the PFCS can be prepared beforehand in the building. Figure 3 shows the results for the cell performance from the instance at which PFCS power started until the commercial power was interrupted. The total current supplied from the fuel cells (IT) increases in three steps because the power of each PFCS started in succession. The forth rapid increase in IT indicates that commercial power is also being generated along with the power from the three PFCSs for a few minutes, until the commercial power is discontinued. In these processes, the voltage (VRT) and the current (IRT) of the RT remains constant. The currents (In) from three PFCSs are almost the same, indicating that the load of the RT is shared equally among the three PFCSs. Here, IT is larger than IRT because a part of IT flows into the batteries. As mentioned above, both PFCS and RT attain steady properties.

Figure 4 shows the long term operating characteristics of the RT with three PFCSs. This experiment was carried out with the interruption of the commercial power for about 5

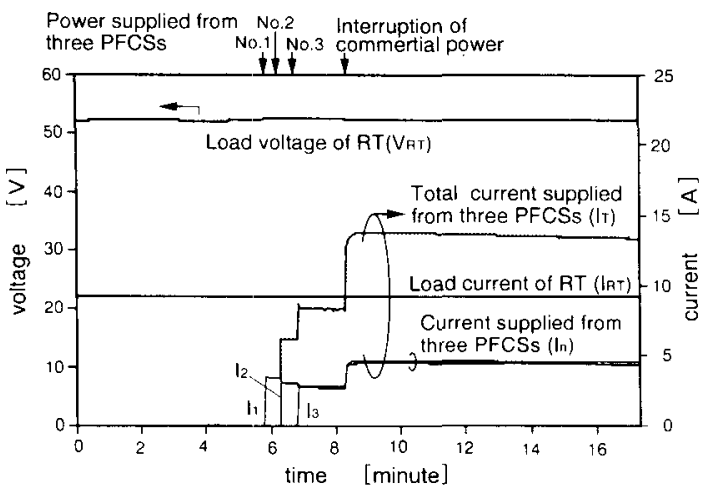

Fig. 3 RT performance characteristics with the PFCS power supply until interruption of commercial power.

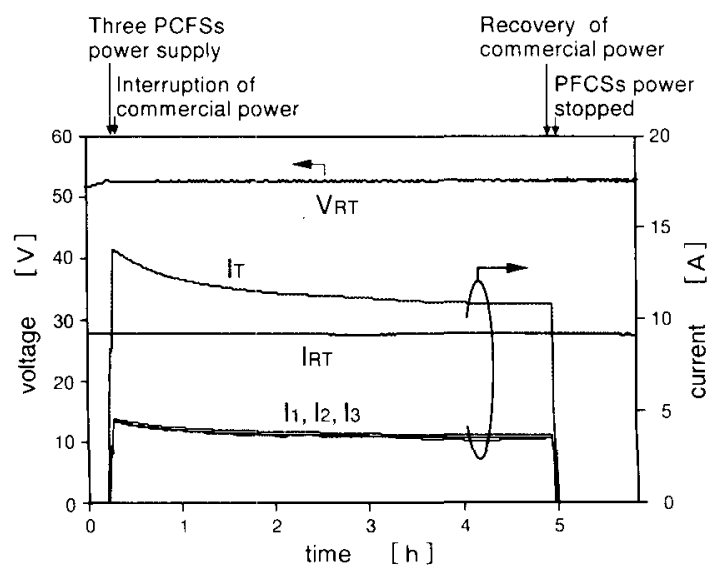

Fig. 4 Long-term operation characteristics of RT with three PECSs.

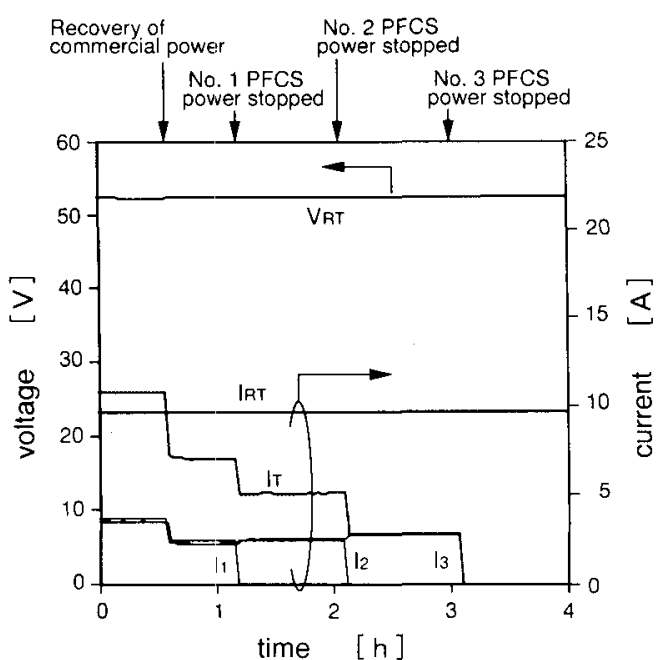

Fig. 5 RT performance characteristics where the PFCS stops power supplies as a result of the recovery of the commercial power. 
hours. IT decreased gradually during this period. This shows the decrease in the charging current from the PFCSs to the batteries. VRT and IRT remains constant during this period. Thus 5 hours of power generation is possible with one cylinder of $\mathrm{H}_{2}$.

Figure 5 shows the power characteristics where the three PFCSs stop generating power as a result of a recovery of the commercial power. Here, IT decreases in four steps corresponding to the recovery of commercial power, and the successive stopping of the three PFCSs's power supplies. After the forth rapid decrease in IT, only the commercial power is supplied. During this entire process, the voltage (VRT) and the current (IRT) of the RT remain constant.

Next, the power supply characteristics of PFCS are monitored for the second case where commercial power is interrupted abruptly without warning. Figure 6 shows the PFCS power supply characteristics when the commercial power was interrupted and the RT was operated by batteries. Here, VRT remains within the standard limits of $48 \pm 5 \mathrm{~V}$. This experiment was based on the shortterm measurements. However, if the RT is operated by the PFCS, long-term operation is possible as long as the hydrogen cylinder is filled. The noise voltage remained less than $5 \mathrm{mV}$.

These results show that PFCS can be used as a back-up power source for intentional or unexpected interruptions of the commercial power.

\subsection{Storing properties of the PFCS}

Figure 7 shows retention of the cell voltage during the storage of PFCS. After 120 days, the voltage decreased about $10 \%$. Figure 8 shows the retained voltage as a function of the number of cycles. Repeated operation tends results in recovery of voltage, here 4 operation cycles results in recovery of up to $97 \%$ of the first-period voltage. The cause for the decrease in the cell voltage may be that the atmospheric humidity enters into the cell stack during the storage period, and this results in a decrease in the concentration of phosphoric acid in the electrolyte ${ }^{6)}$. The concentration of the solution is considered to increase by the repeated operation. These results show that PFCS can be used as the emergency power source for RT.

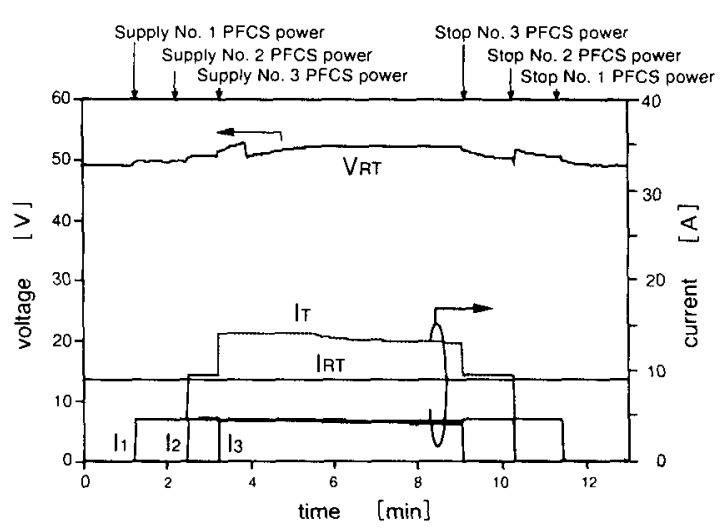

Fig. 6 PECS power supply characteristics when the $\mathrm{RT}$ is operated by batteries.

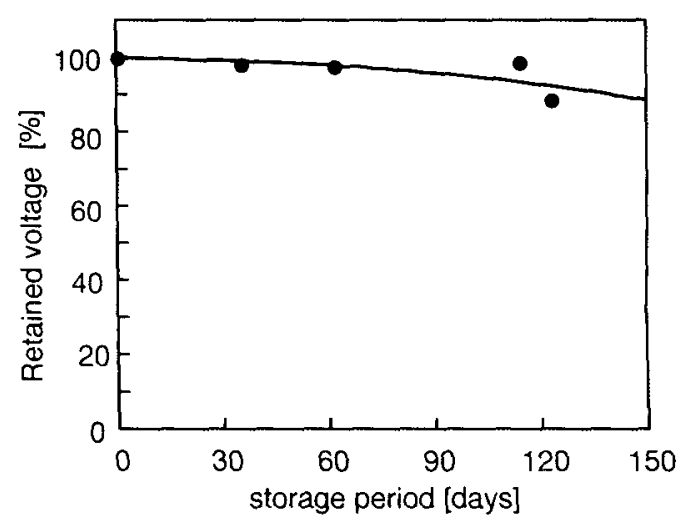

Fig. 7 Retained voltage as a function of storage time.

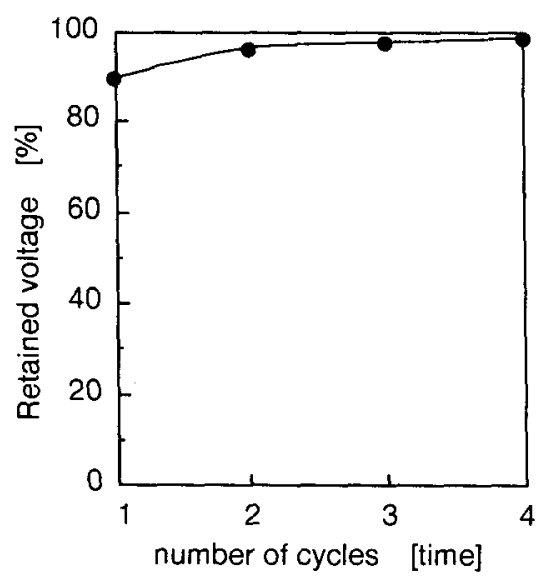

Fig. 8 Retained voltage as a function of the number of cycles. 


\section{SUMMARY}

A portable fuel cell system (PFCS) has been developed and used as an emergency power source of a telecommunications system.

The PFCS consists of a small fuel cell, a hydrogen cylinder, a 55 V DC-DC converter, and a carrier. The PFCS supplies $250 \mathrm{~W}$ DC power for 5 hours; this power is generated by hydrogen fuel from $10.5 \ell$ hydrogen cylinder. The DC-DC converter can allocate the current equally to each PFCS and the parallel connection between the PFCSs increase the power that can be generated for the telecommunications equipment. Three PFCSs can be operated simultaneously to supply the power to remote terminals (RT). The telecommunications system operated stably and the PFCS had a good storage reliability, thereby indicating that the PFCS can be used as a back-up power source in the case of the intentional or unexpected interruptions in the commercial power.

\section{References}

1) T. Koyashiki, R. Okada, Y. Kuwata, M. Ishizawa and $\mathrm{K}$. Ohshima, L'Onde Electrique, 72, 9 (1993).
2) N. Asano, T. Koyashiki and M. Nakao, NTT REVIEW, 6, 47 (1994).

3) Y. Kuwata, R. Tanaka and M. Iwasawa, NTT REVIEW, 6, 54 (1994).

4) K. Ohshima, T. Uekusa, M. Ishizawa and T. Kameyama, NTT REVIEW, 6, 59 (1994).

5) M. Ishizawa, S. Iida and I. Abe, T.IEE Japan, 115-B, 1480 (1995).

6) K. Nakatoh, K. Shindoh, N.Nishizawa and M. Tsutsumi, The 2nd FCDIC Fuel Cell Symposium Proceedings, 82 (1995).

7) Y. Kuwata, M. Ishizawa, T. Take and T. Koyashiki, The 2nd FCDIC Fuel Cell Symposium Proceedings, 92 (1995).

8) A. Watanabe, H. Mukai, N. Nishizawa, T. Itoh and Y. Nomura, SANYO TECHNICAL REVIEW, 26, 18 (1994).

9) I. Sakakibara and F. Higashiyama, NTT REVIEW, 3, 21 (1991).

10) Y. Iguchi and S. Hashiba, NTT REVIEW, 3, 27 (1991).

11) T. Doi, K.Murakami, S. Hashiba and M. Shiozawa, NTT REVIEW, 7, 75 (1995).

12) I. Doi, K. Murakami, O. Hanazaki, S. Hashiba and A. Kobayashi, NTT R\&D, 44, 676 (1995). 